\title{
Asas Kepentingan Umum dalam Pengadaan Tanah untuk Kepentingan Negara
}

\author{
Dede Yusuf, Suwari Akhmaddhian \\ Fakultas Hukum, Universitas Kuningan, Indonesia \\ Email : dedeyusuf@gmail.com
}

\begin{abstract}
Legal arrangements regarding land acquisition for public use in Indonesia have undergone a process of development since the unification of the Basic Agrarian Law No. 5 of 196o. However, in practice this provision has caused many problems that cannot be carried out effectively. Then the government issued Presidential Decree Number 55 of 1993, as revoked by Presidential Regulation Number 36 of 2005 concerning the release or transfer of land rights, which was then revised by Presidential Regulation Number 65 of 2006. Various problems existed in the acquisition of land for development for public use tried to be minimized through these regulations. Even though changes have been made to perfect the laws and regulations regarding land acquisition for development in the public interest in order to provide justice and welfare for the community, but there are still some juridical issues in the laws and regulations that escaped the attention of the drafters of the laws and regulations. invitation, which includes formal juridical aspects and material juridical aspects.
\end{abstract}

Keywords: Principle of Public interest, land acquisition.

\begin{abstract}
Abstrak
Pengaturan hukum tentang pengadaan tanah untuk kepentingan umum di Indonesia telah mengalami proses perkembangan sejak unifikasi Undang-Undang Pokok Agraria Nomor 5 Tahun 1960. Namun dalam praktiknya ketentuan ini banyak menimbulkan masalah sehingga tidak dapat berjalan dengan efektif. Kemudian pemerintah mengeluarkan Keputusan Presiden Nomor 55 Tahun 1993, sebagaimana dicabut dengan Peraturan Presiden Nomor 36 Tahun 2005 mengenai pelepasan atau penyerahan hak atas tanah, yang kemudian direvisi oleh Peraturan Presiden Nomor 65 Tahun 2006. Berbagai masalah yang terdapat dalam pengadaan tanah bagi pembangunan untuk kepentingan umum telah coba diminimalisir melalui peraturan-peraturan tersebut. Meskipun telah diadakan perubahan-perubahan untuk menyempurnakan peraturan perundang-undangan mengenai pengadaan tanah bagi pembangunan untuk kepentingan umum dalam rangka memberikan keadilan dan kesejahteraan bagi masyarakat, namun tetap saja ada beberapa permasalahan yuridis dalam peraturan perundang-undangan tersebut yang luput dari perhatian penyusun peraturan perundang-undangan, yaitu meliputi aspek yuridis formal dan aspek yuridis materiil.
\end{abstract}

Kata Kunci : Asas Kepentingan umum, pengadaan tanah.

\section{PENDAHULUAN}

Negara didirikan demi kepentingan umum dan hukum adalah sarana utama untuk merealisasikan tujuan itu. Salah satu isu pokok yang sering dipermasalahkan dimasa lalu adalah mengenai definisi kepentingan umum. Pada pasal 18 UUPA diatur bahwa untuk kepentingan umum termasuk kepentingan bangsa dan Negara serta kepentingan bersama dari rakyat hak-hak atas tanah dapat dicabut dengan memberi ganti kerugian yang layak dan menurut cara yang diatur dengan undang-undang. Pengadaan tanah oleh pihak swasta, maka cara - cara yang dilakukan adalah melalui jual - beli, tukar menukar, atau cara lain yang disepakati oleh pihak - pihak yang bersangkutan, yang dapat dilakukan secara langsung antara pihak yang berkepentingan dengan pemberian ganti kerugian yang besar atau jenisnya ditentukan dalam musyawarah.

Sedangkan dalam hal pengadaan tanah oleh pemerintah atau pemerintah daerah untuk pelaksanaan pembangunan demi kepentingan umum dapat dilaksanakan dengan 
Logika : Journal of Multidisciplinary Studies, p-ISSN 2085-9970. e-ISSN 2715-4505

Vol. 10 Nomor 02 Desember 2019. 100-105

cara pelepasan atau penyerahan hak atas tanah, atau juga dengan pencabutan hak atas tanah.Pengadaan tanah untuk pelaksanaan pembangunan demi kepentingan umum dilakukan melalui musyawarah dengan tujuan memperoleh kesepakatan mengenai pelaksanaan pembangunan di lokasi yang ditentukan, beserta bentuk dan besar ganti kerugian. Sehubungan dengan kewenangan ini, untuk menyelenggarakan penyediaan tanah dalam keperluan masyarakat dan negara, pemerintah dapat mencabut hak-hak atas tanah dengan memberikan ganti kerugian yang layak menurut cara yang diatur dengan undang-undang. ${ }^{1}$ Apabila upaya melalui cara musyawarah gagal membawa hasil.

${ }^{2}$ Berdasarkan lata belakang di atas maka rumusan masalah dalam penelitian ini adalah: Bagaimana Pengadaan Tanah Untuk Kepentingan Umum ? dan Bagaimana Pengadaan Tanah Untuk Kepentingan Swasta?

\section{METODE PENELITIAN}

Metode penelitian yang digunakan oleh penulis adalah yuridis normatif, dengan alat pengumpul data melalui studi kepustakaan yaitu studi dokumentasi peraturan

\section{PEMBAHASAN}

Menurut Mudakir Iskandar Syah (2007) bahwa bila dibandingkan dengan definisi kepentingan umum diatas maka rumusan kepentingan umum yang terddapat dalam perpres no 36 tahun 2005 jo perpres no 65 tahun 2006 adalah lebih tepat dengan menggunukan rumusan "sebagian besar lapisan masyarakat" oleh karena salah satu sarana umum itu belum tentu dapat dinikmati semua masyarakat kata "sebagian besar" mempunyai arti tiak semua masyarakat namun dapat dianggap untuk semua masyarakat walaupun dari sebagian besar itu ada sebagian kecil masyarakat yang tidak bisa menikmati hasil atau manfaat dari fasilitas pembangunan kepentingan umum itu sendiri. Pengertian Kepentingan Umum, Dalam koppres no 55/1993 telah memberikan klarifikasi dan definisi yang tegas mengenai kepentingan umum yaitu :

1. Kepentingan seluruh masyarakat

2. Kegiatan pembangunan yang dilakukan dimiliki oleh pemerintah

3. Tidak dipergunakan untuk mencari keuntungan

Dengan demikian interpretasi tentang kegiatan termasuk dalam kategori kepentingan umum dibatasi pada terpenuhinya ketiga unsur terrsebut secara komulatif. Selanjutnya dalam perpres no 36 tahun 2005 jo perpres no 65 tahun 2006 disebutkan bahwa yang dimaksud dengan kepentingan umum adalah kepentingan sebagian besar lapisan masyarakat. Kepentingan umum adalah kepentingan yang menyangkut kepentingan Negara, bangsa dan sebagian besar masyarakat.

Kepentingan umum adalah suatu kepentingan yang menyangkut semua lapisan masyarakat tanda pandang golongan, suku, agama, status social dan sebagainya. Berarti apa yang dikatakan kepentingan umum ini menyangkut hajat hidup orang banyak

\footnotetext{
${ }^{1}$ Indonesia, Undang-Undang Tentang Peraturan Dasar Pokok-Pokok Agraria, UU No. 5 tahun 196o, Pasal 18.

2 Indonesia, Penjelasan Umum Undang-Undang Tentang Pencbutan hak-hak Atas tanah dan Benda-Benda yang ada diatasnya, UU No 20 Tahun 1961
} 
Logika : Journal of Multidisciplinary Studies, p-ISSN 2085-9970. e-ISSN 2715-4505

Vol. 10 Nomor 02 Desember 2019. 100-105

bahkan termassuk hajat bagi orang yang telah meninggal atau dengan kata lain hajat semua orang $\mathrm{s}^{3}$.

Pengertian Pengadaan Tanah, Menurut Pasal 1 angka 3 Perpres No.65/2006, yang dimaksud dengan Pengadaan Tanah adalah setiap kegiatan untuk mendapatkan tanah dengan cara memberikan ganti kerugian kepada yang melepaskan atau menyerahkan tanah, bangunan, tanaman dan benda-benda yang berkaitan dengan tanah.Dengan demikian dapat disimpulkan bahwa pengadaan tanah menurut Perpres No.65/2006 selain dengan memberikan ganti kerugian juga dimungkinkan untuk dapat dilakukan dengan cara pelepasan hak. Masalah tanah adalah masalah bangsa dan negara, sehingga juga masalah kita semua anak bangsa yang hidup diseluruh nusantara. Artinya tanah merupakan hal yang fundamental bagi kita semua. Dalam perkembangannya masalah tanah semaki kompleks, sehingga dimensinyapun bertambah terus mengikuti dinamika derat langkah pembangunan bangsa ini, antara lain dimensi yuridis, ekonomis, politis, sosial, religius magis, bahkan bagi negara tanah mempunyai dimensi strategis. ${ }^{4}$

Pengadaan Tanah Untuk Umum, Secara sederhana dapat diartikan bahwa kepentingan umum dapat saja dikatakan untuk keperluan, kebutuhan atau kepentingan orang banyak atau tujuan yang luas. Namun demikian rumusan tersebut terlalu umum dan tidak ada batasannya.Kepentingan umum adalah termasuk kepentingan bangsa dan negara serta kepentingan bersama dari rakyat, dengan memperhatikan segi-segi sosial, politik, psikologis dan hankamnas atas dasar asas-asas Pembangunan Nasional dengan mengindahkan Ketahanan Nasional serta Wawasan Nusantara. Jenis-jenis pembangunan untuk kepentingan umum adalah sebagai berikut:

1. Jalan umum, saluran pembuangan air;

2. Waduk, bendungan dan bangunan pengairan lainnya termasuk saluran irigasi;

3. Rumah Sakit Umum dan Pusat-pusat Kesehatan Masyarakat;

4. Pelabuhan atau Bandara atau Terminal;

5. Peribadatan;

6. Pendidikan atau sekolahan;

7. Pasar Umum atau Pasar INPRES;

8. Fasilitas Pemakaman Umum;

9. Fasilitas Keselamatan Umum seperti tanggul penanggulangan bahaya banjir, lahar;

10. Pos dan Telekomunikasi;

11. Sarana Olah Raga;

12. Stasiun Penyiaran Radio, Televisi beserta sarana pendukungnya;

13. Kantor Pemerintah;

14. Fasilitas Angkatan Bersenjata Republik Indonesia.

Selanjutnya telah mengalami perubahan yaitu dengan diterbitkannya Perpres RI

No. 65 Tahun 2006. Pasal 5 Perpres RI No. 65 Tahun 2006 menyebutkan pembangunan untuk kepentingan umum yang dilaksanakan pemerintah atau pemerintah daerah

\footnotetext{
3 Suwari Akhmaddhian, Asas-Asas dalam Penyelenggaraan Pemerintahan yang Baik untuk Mewujudkan Good Governace, Logika : Journal of Multidisciplinary Studies, ISSN 2085-9970. Vol. og Nomor o1 Juni 2018. 30-38.

4Darwin Ginting, "kapita slekta hukum agraria”, Jakarta: fokusindo mandiri, 2013, 122.
} 
Logika : Journal of Multidisciplinary Studies, p-ISSN 2085-9970. e-ISSN 2715-4505

Vol. 10 Nomor 02 Desember 2019. 100-105

sebagaimana dimaksud dalam pasal 2, yang selanjutnya dimiliki atau akan dimiliki oleh pemerintah atau pemerintah daerah, meliputi :

1. jalan umum dan jalan tol, rel kereta api (di atas tanah, di ruang atas tanah, atau pun di ruang bawah tanah), saluran air minum/air bersih, saluran pembuangan air dan sanitasi;

2. waduk, bendungan, bendungan irigasi dan bangunan pengairan lainnya;

3. pelabuhan, bandar udara, stasiun kereta api, dan terminal;

4. fasilitas keselamatan umum, seperti tanggul penanggulangan bahaya banjir, lahar, dan lain bencana;

5. tempat pembuangan sampah

Adapun Prosedur/Tata Cara Pengadaan Tanah Untuk Kepentingan Umum. Dengan berlakunya Perpres No.65/2006, maka ada perbedaan dalam tata cara pengadaan tanah untuk kepentingan umum. Menurut Pasal 2 Perpres No.65/2006 menyatakan bahwa:

1. Pengadaan tanah bagi pelaksanaan pembangunan untuk kepentingan umum oleh pemerintah atau Pemerintah Daerah dilaksanakan dengan cara pelepasan atau penyerahan hak atas tanah.

2. Pengadaan tanah selain bagi pelaksanaan pembangunan untuk kepentingan umum oleh Pemerintah atau Pemerintah Daerah dilakukan dengan cara jual beli, tukar menukar, atau cara lain yang disepakati secara sukarela oleh pihak-pihak yang bersangkutan."

Pengadaan tanah untuk kepentingan swasta adalah kepentingan yang diperuntukkan memperoleh keuntungan semata, sehingga peruntukan dan kemanfaatannya hanya dinikmati oleh pihak-pihak tertentu bukan masyarakat luas. Sebagai contoh untuk perumahan elit, kawasan industri, pariwisata, lapangan golf dan peruntukan lainnya yang bertujuan untuk memperoleh keuntungan semata. Jadi tidak semua orang bisa memperoleh manfaat dari pembangunan tersebut, melainkan hanya orang-orang yang berkepentingan saja.

Dengan demikian dapat disimpulkan bahwa menurut Perpres No.65/2006, bahwa khusus untuk pengadaan tanah bagi kepentingan umum yang dilaksanakan oleh Pemerintah atau Pemerintah Daerah dilakukan dengan cara pelepasan atau penyerahan hak atas tanah, sedangkan pengadaan tanah selain untuk kepentingan umum yang dilaksanakan oleh Pemerintah atau Pemerintah Daerah, dalam hal ini dilakukan oleh pihak swasta, maka dilaksanakan dengan jual beli, tukar menukar, atau cara lain yang disepakati secara sukarela oleh pihak-pihak yang bersangkutan. Dasar Hukum yang mengatur pengadaan tanah yaitu :

1. Undang-undang nomor 2 tahun 2012 tentang pengadaan tanah bagi pembangunan untuk kepentingan umum.

2. Undang undang nomor 28 tahun 1999 tentang penyelenggaraan negara.

3. Perpres RI No. 65 Tahun 2006 tentang pengadaan tanah

Direktorat Tindak Pidana Korupsi (Dit Tipidkor) Bareskrim Polri menetapkan Yusafni sebagai tersangka dalam kasus dugaan tindak pidana korupsi pengadaan tanah 
Logika : Journal of Multidisciplinary Studies, p-ISSN 2085-9970. e-ISSN 2715-4505

Vol. 10 Nomor 02 Desember 2019. 100-105

untuk pembangunan infrastruktur strategis di Dinas Prasarana Jalan, Tata Ruang dan Permukiman (Prasjal dan Tarkim) Provinsi Sumatera Barat tahun 2012-2016.

Tersangka Yusafni adalah Pejabat Pembuat Komitmen (PPK) dan Pejabat Pelaksana Teknis Kegiatan (PPTK) di dinas tersebut. Dia ditangkap oleh polisi pada Kamis 27 Juli 2017 di Bandara Internasional Soekarno Hatta. Proyeknya adalah pengadaan tanah untuk pembangunan infrastruktur strategis pada Dinas Prasarana Jalan, Tata Ruang dan Permukiman Provinsi Sumatera Barat. Ada kegiatan pengadaan lahan dari tahun 20122016. Ada indikasi penyimpangan dari hasil penyidikan penggantian ganti rugi tanah. Kerugian negara akibat proyek ini diduga mencapai Rp 6o miliar dari total proyek Rp 120 miliar. Modusnya yaitu, yang bersangkutan melakukan penyimpangan pertanggungjawaban. Jadi ada semacam fiktif, ada yang dua kali. Tidak dibayarkan kepada pemilik lahan, tapi digunakan untuk kepentingan pribadi. Atas perbuatannya, Bareskrim menyangka Yusafni melanggar Pasal 2 ayat (1) dan atau Pasal 3 UndangUndang Nomor 31 tahun 1999 tentang Pemberantasan Tindak Pidana Korupsi yang telah diubah dangan UU Nomor 20 tahun 2001 tentang Perubahan atas UU Nomor 31 tahun 1999 tentang Pemberantasan Tindak Pidana Korupsi Jo Pasal 55 Ayal (1) ke-1 KUHP.

\section{SIMPULAN}

Pengaturan hukum tentang pengadaan tanah untuk kepentingan umum di Indonesia telah mengalami proses perkembangan sejak unifikasi Undang-Undang Pokok Agraria Nomor 5 Tahun 1960.. Namun dalam praktiknya ketentuan ini banyak menimbulkan masalah sehingga tidak dapat berjalan dengan efektif. Kemudian pemerintah mengeluarkan Keputusan Presiden Nomor 55 Tahun 1993, sebagaimana dicabut dengan Peraturan Presiden Nomor 36 Tahun 2005 mengenai pelepasan atau penyerahan hak atas tanah, yang kemudian direvisi oleh Peraturan Presiden Nomor 65 Tahun 2006. Berbagai masalah yang terdapat dalam pengadaan tanah bagi pembangunan untuk kepentingan umum telah coba diminimalisir melalui peraturan-peraturan tersebut. Meskipun telah diadakan perubahan-perubahan untuk menyempurnakan peraturan perundangundangan mengenai pengadaan tanah bagi pembangunan untuk kepentingan umum dalam rangka memberikan keadilan dan kesejahteraan bagi masyarakat, namun tetap saja ada beberapa permasalahan yuridis dalam peraturan perundang-undangan tersebut yang luput dari perhatian penyusun peraturan perundang-undangan, yaitu meliputi aspek yuridis formal dan aspek yuridis materiil.

\section{SARAN}

Pengadaan tanah untuk kepentingan umum dengan mengambil tanah milik masyarakat umum sangat berkaitan erat dengan masalah Hak Asasi Manusia, maka seharusnya pengaturannya segera dimuat di dalam Undang Undang.

\section{DAFTAR PUSTAKA}

Darwin Ginting, "kapita slekta hukum agraria", Jakarta: fokusindo mandiri, 2013. Indonesia, Undang-Undang Tentang Peraturan Dasar Pokok-Pokok Agraria, UU No. 5 tahun 196o, Pasal 18. 
Logika : Journal of Multidisciplinary Studies, p-ISSN 2085-9970. e-ISSN 2715-4505

Vol. 10 Nomor 02 Desember 2019. 100-105

Indonesia, Penjelasan Umum Undang-Undang Tentang Pencbutan hak-hak Atas tanah dan Benda-Benda yang ada diatasnya, UU No 20 Tahun 1961

Suwari Akhmaddhian, Asas-Asas dalam Penyelenggaraan Pemerintahan yang Baik untuk Mewujudkan Good Governace, Logika : Journal of Multidisciplinary Studies, ISSN 2085-9970. Vol. o9 Nomor o1 Juni 2018. 30-38.

Undang-undang nomor 2 tahun 2012 tentang Pengadaan Tanah bagi Pembangunan untuk Kepentingan Umum

Undang undang nomor 28 tahun 1999 tentang Penyelenggaraan Negara

Perpres RI No. 65 Tahun 2006 tentang Pengadaan Tanah 